\title{
OBSERVATIONS ON THE ARTISANAL PRAWN FISHERY IN THE SHALLOW COASTAL WATERS OFF CHILAW DURING 1994-1995.
}

\author{
P. A. A. T. JAYAWARDANE ${ }^{*}$ and D. S. JAYAKODY \\ National Aquatic Resources Research and Development Agency (NARA). Crow Island, \\ Mattakkuliya, Colombo 15
}

(Received: 24 February 1998 ; accepted: 07 February 2000)

\begin{abstract}
A study was conducted to assess the impact of the imposition of the ban on the prawn trawl fishery in Chilaw area on the artisanal prawn fishery in the shallow coastal waters off Chilaw from January 1994 to December 1995. Fishing operations were mainly carried out hy the traditional log rafts. In addition a few FRP boats were also engaged in exploitation of the resource. Thammel nets were the most widely used gear in the artisanal prawn fishery. Fishermen in the study area also used encircling gillnets seasonally to exploit the small prawn resources. The mesh size of the trammel nets used ranged from $32.50 \mathrm{~mm}$ while the mesh size used in the encircling gillnets was the $7 \mathrm{~mm}$ stretched mesh. Total catch, effort and the catch per unit effort showed seasonal variations. The average catch rates recorded for the $\mathrm{craft} / \mathrm{gear}$ combinations log raft/trammel net and FRP/trammel net during the present investigation were $3.74 \mathrm{~kg} / \mathrm{craft} /$ day and $7.25 \mathrm{~kg} / \mathrm{cr}$ aft/day respectively. The total annual productions from the artisanal prawn fishery were $92 \mathrm{MT}$ and $68 \mathrm{MT}$ for 1994 and 1995 fishing seasons respectively. In addition the estimated total fish productivity from the seasonal fishing operations in the 1995 fishing season was 17 MT. These productions were quite low compared to the estimates made for the prawn trawl fishery for the periods 1979-1980 and 1980-1981. A total of 31 species of finfish and shellfish have been identified among the catches. Of the important crustacean species Pennens indicus, Penueus merguiensis, Poncueus semisulcatus and Portumus pelagicus dorninated the catches while Leiognathus spp. and sciaenids were among the finfish species caught.
\end{abstract}

Key words: Chilaw, log rafts, Penueus, prawn fishery, trammel nets

\section{INTRODUCTION}

Prawns are considered as a luxury food commodity in international trade. They supply an increasing population with proteins and provide significant earnings of foreign exchange. The prawn industry has thus assumed major importance in recent years in Sri Lanka. ${ }^{1}$ The most productive fisshing grounds and the majority of species of high commercial interest are found in the tropics. ${ }^{2}$ Most of the artisanal production of prawns in Sri Lanka comes from lagoons. ${ }^{3}$ The penaeid prawns of Sri Lanka from estuaries and sea are important commercial fishery resources. ${ }^{4}$ Thirty one species of prawns have been recorded off Sri Lanka. ${ }^{5}$

Fishery for prawns in estuaries, lagoons and the shallow coastal areas of the seas off Sri Lanka has a long history. Prior to the introduction of the mechanization to the fishing industry in Sri Lanka prawn resources have been 
extensively exploited using the traditional fishing methods in the different regions of the country. Prawns contribute around $3 \%$ by weight of the total marine landings of the island. Out of this $20 \%$ comes from Negombo and Chilaw which are the major prawn landing centres of the country. ${ }^{i}$ In addition cultured prawns contribute significantly to the foreign exchange earnings from aquatic products and the percentage contribution has varied from $48 \%$ to $70 \%$ in the recent years. ${ }^{7}$

Artisanal prawn fishery has been in existence in the seas off Chilaw over the years. A ban on prawn trawl fishery was imposed in Chilaw in 1992. Since then the artisanal prawn fishery has been mainly responsible for prawn catches from the Chilaw area. The present study was conducted to investigate the impact of the ban imposed on prawn trawl fishery on the traditional prawn fishery in the shallow coastal waters off Chilaw. The present investigations of the traditional prawn fishery included studies on catch and effort, species, length composition of catches and specifications of the crafts and gear.

\section{METHODS AND MATERIALS}

The artisanal prawn fishery in the shallow coastal areas off Chilaw was studied for a two year period from January 1994 to December 1995. Initially a frame survey was carried out along the study area to identify tish landing centres which represent different craft/gear combinations in the fishery. From around 08 fish landing centres scattered along the study area ${ }^{8}$ two major fish landing centres, Chilaw and Welihena were selected for sampling.

Every second week, the selected fish landing centres were visited to collect information on fish catch, fishing effort, gear details, species composition of the catches and the length measurements of the commercially important species. Of the total number of crafts operated, 20 - 40 percent were sampled at each sampling site.

The total number of crafts operated/day was taken as the unit of measure of the effort of this fishery. These values were derived for each month by averaging total number of crafts operated on sampling days. This was used to calculate the percentage of crafts operated in each month at the sampling site and this was then extrapolated to obtain an estimate for the study area.

The average catch/craft/day was considered as the catch per unit effort for each month. The total catch for a day was estimated by multiplying the total number of crafts operated on a sampling day by the average catch per craft sampled. To obtain the monthly total catch, the estimated daily total catch was multiplied by the number of fishing days in each month (generally around 23 -26). 


\section{RESULTS}

\section{Fishing crafts and gear}

The prawn resources in the shallow coastal areas off Chilaw are harvested by around 200 traditional $\log$ rafts (LR) scattered throughout the study area. In addition there were around 80 fibre reinforced plastic (FRP) boats operated around the sea mouth of the Chilaw Estuary especially during the period from January to April of each year.

The fishing gear used are trammel nets (TN) which are made up of nylon multifilament twine. Each net consists of number of equal size net pieces (each piece is 1500 mesh long and 65 mesh wide). The size of the net is determined by the number of these net pieces. The number of such units used for a single operation varied from $4-20$ (Mean $=11.7 \mathrm{SD}=3.55)$ for log rafts while for FRP boats they varied from $8-32($ Mean $=15.4 \mathrm{SD}=6.41)($ Table 1$)$.

Table 1: Specifications of the craft and gear used in the artisanal prawn fishery

\begin{tabular}{lllll}
\hline $\begin{array}{l}\text { Fishing } \\
\text { craft/gear } \\
\text { combination }\end{array}$ & $\begin{array}{l}\text { Number of net pieces used } \\
\text { in one operation }\end{array}$ & $\begin{array}{l}\text { Range of } \\
\text { mesh size } \\
(\text { stretched } \\
(\mathrm{mm})\end{array}$ & $\begin{array}{l}\text { Depth of } \\
\text { operation } \\
(\mathrm{m})\end{array}$ & $\begin{array}{l}\text { Number of } \\
\text { fishing } \\
\text { trips per } \\
\text { day }\end{array}$ \\
\hline
\end{tabular}

\begin{tabular}{lcccccc}
\hline & Range & Mean & $\begin{array}{c}\text { Std. } \\
\text { Deviation }\end{array}$ \\
\cline { 2 - 7 } LR/TN & $4-20$ & 11 & 3.55 & $38-50$ & $5.47-18.24$ & 01 \\
FRP/TN & $8-32$ & 15.4 & 6.41 & $32-45$ & $3.66-14.64$ & 01 \\
\hline
\end{tabular}

\section{Fishing effort}

The traditional prawn fishery in the shallow coastal areas off Chilaw is highly seasonal due to the inability of carrying out fishing operations during the south west monsoonal period with prevailing unfavourable weather conditions. The fishing operations were generally therefore restricted to the periods January - April and October - December during both years studied.

The total annual fishing effort (number of fishing operations) in the study area was estimated at 20,808 for the year 1994 . Of this fishing effort, $83 \%$ was carried out by traditional log rafts and the remaining $17 \%$ by FRP boats. The following year, the fishing effort in the study area dropped from close to 20,000 fishing operations to slightly over 18,800 fishing operations which is a drop of about $9 \%$. The composition of the annual fishing effort does not show considerable change 
during the two years studied. There is a tendency for an increase in effort during the period November to January (Fig. 1a). The variation pattern of the effort was the same for the two years covered during the present investigation.

\section{Catch rates}

The catch rates of the two different craft/gear combinations does not show considerable variations. Highest catch rates of $9.96 \mathrm{~kg} /$ operation and 10.67 $\mathrm{kg} /$ operation for the years 1994 and 1995 were recorded for the craft/gear combinations log raft/trammel nets and FRP/trammel nets respectively. During the present investigation the average catch rates recorded for the craft/gear combinations log raft/trammel nets and FRP/trammel nets were $3.74 \mathrm{~kg} / \mathrm{boat} /$ day and $7.25 \mathrm{~kg} /$ boat/day respectively. In general the average catch per effort dropped for both craft/gear combinations between 1994 and 1995. The variation patterns of the catch rates of the two different craft/gear combinations were found to be similar in both years studied (Fig. 1b). There is a trend for the catch/effort to increase in October - November and decline to a minimum in March.

\section{Total catch}

The annual fish catch from the traditional prawn fishery in the study area was estimated at $92 \mathrm{MT}$ in 1994 and $68 \mathrm{MT}$ in 1995. This was approximately a $26 \%$ reduction in the fish catch. Contribution of the trammel nets operated by the $\log$ rafts to the total production of the fishery was around $69 \%$. The variation pattern of the total production was the same for both craft types and for the two years studied (Fig. 1c). Generally the period November to February could be considered as the peak period for the fishery though high catches were observed in the month of April of both the years studied.

\section{Species and size composition of the catches}

A total of 31 species of finfish and shellfish belonging to 14 families with some commercial value were identified among the catches (Appendix 1). Almost all the finfish and shellfish species caught are of marine origin. Although a number of species are fished and have some commercial value, only a few dominate the catches in terms of weight and/or value. Of the important crustacean species $P$. indicus, $P$. merguiensis, $P$. semisulcatus and Portunus pelagicus (sea crab) dominated the catches and Leiognathus spp. and sciaenids were among the finfish species caught. Two major craft/gear combinations used in the study area (FRP/TN and LR/TN) have not shown a difference in catch composition (Fig. $2 \mathrm{a}$ and Fig. 2b) since both targeted the more valuable prawns.

Due to the narrow range of the mesh sizes used in the traditional prawn fishery ( $32-50 \mathrm{~mm}, 38$ being the most common) there is no considerable size range 
a. effort

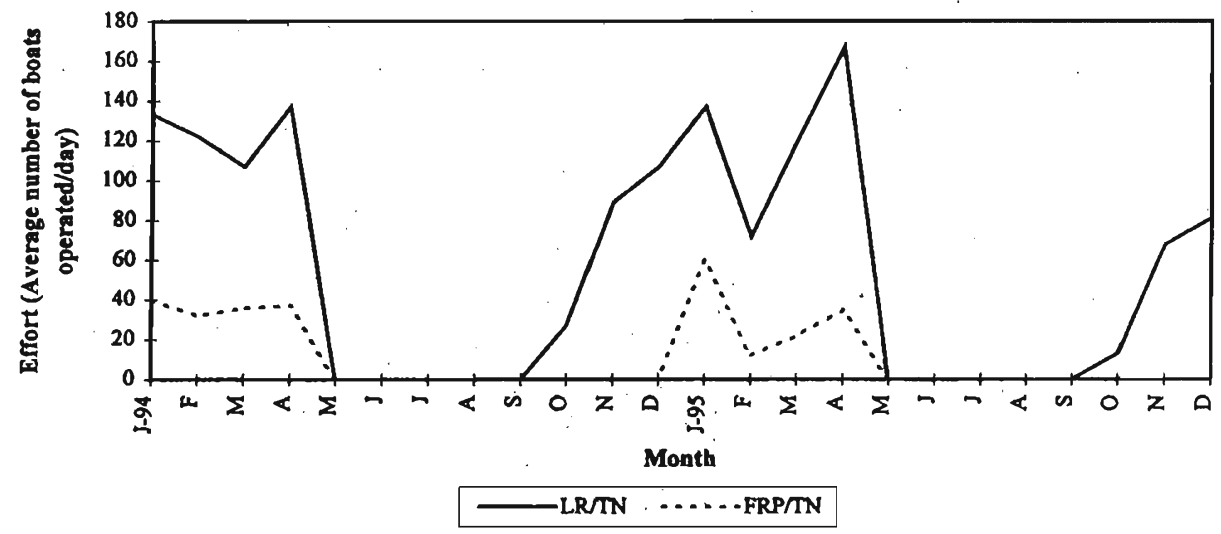

b. catch rate

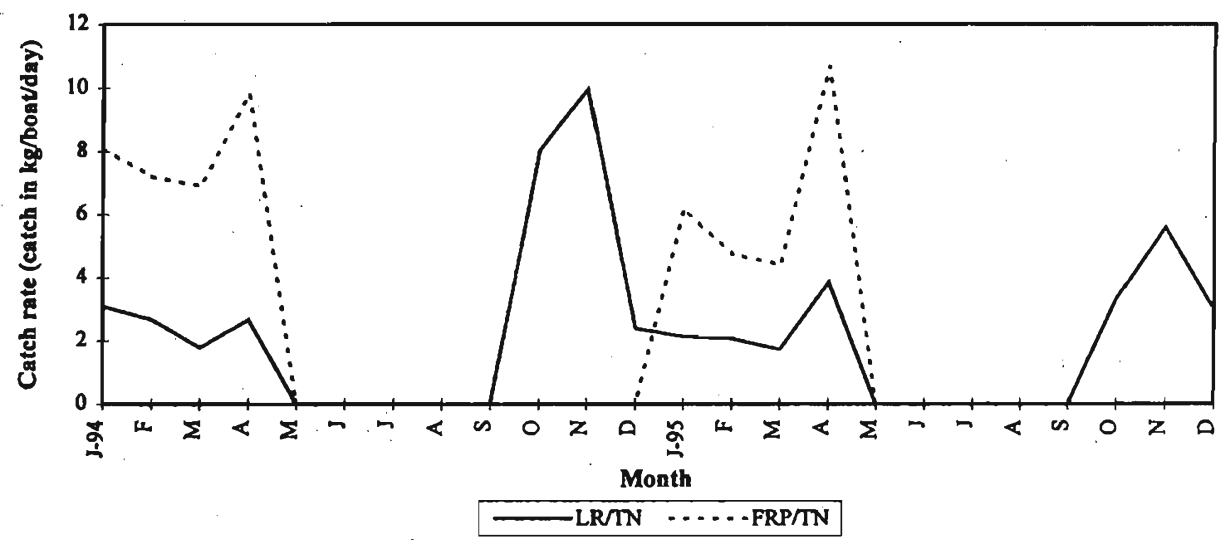

c. total production

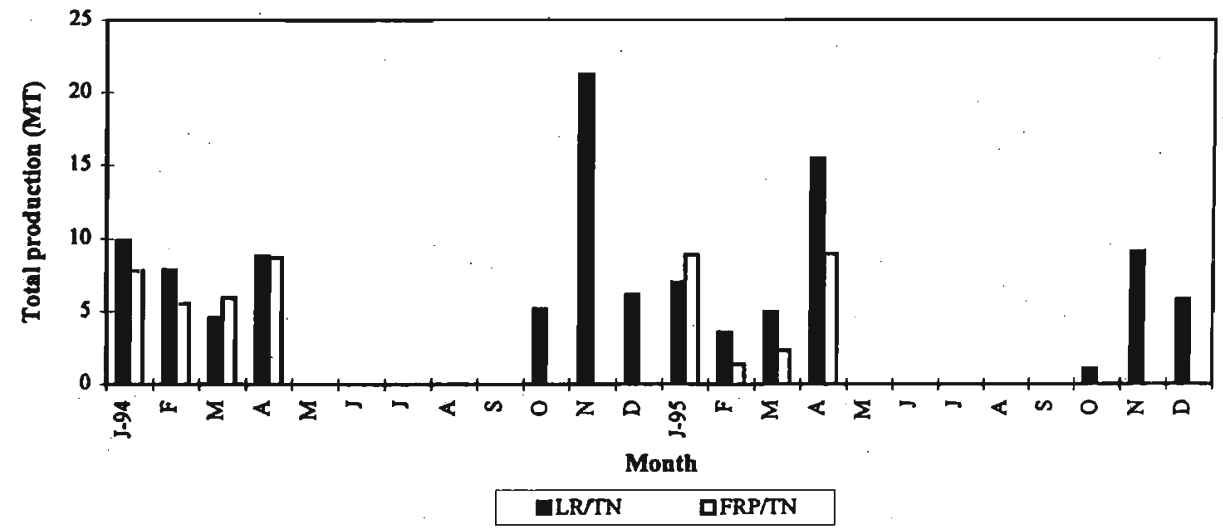

Figure 1: Monthly variation in the fishing effort, catch rate and the total production of the artisanal prawn fishery 
Appendix 1- List of species identified among the catches

\begin{tabular}{|c|c|c|}
\hline$\overline{\text { Family }}$ & Scientific name & English name \\
\hline Penaeidae & $\begin{array}{l}\text { Penaeus indicus } \\
\text { Penaeus merguiensis } \\
\text { Penaeus monodon } \\
\text { Penaeus semisulcatus } \\
\text { Metapenaeus dobsoni }\end{array}$ & $\begin{array}{l}\text { Indian white shrimp } \\
\text { Banana prawn } \\
\text { Giant tiger prawn } \\
\text { Green tiger prawn } \\
\text { Kadal shrimp }\end{array}$ \\
\hline Clupeidae & $\begin{array}{l}\text { Hilsa kelee } \\
\text { Escualosa thoracata. }\end{array}$ & $\begin{array}{l}\text { Kelee shad } \\
\text { White sardine }\end{array}$ \\
\hline Pristigasteridae & $\begin{array}{l}\text { Opisthopterus tardoore } \\
\text { Pellona ditchela } \\
\text { Ilisha elongata }\end{array}$ & $\begin{array}{l}\text { Tardoore } \\
\text { Indian pellona } \\
\text { Elongate ilisha }\end{array}$ \\
\hline Scombridae & $\begin{array}{l}\text { Rastrelliger kanagurta } \\
\text { Scomberomorus commerson }\end{array}$ & $\begin{array}{l}\text { Indian mackerel } \\
\text { Narrowbarred spanish } \\
\text { mackerel }\end{array}$ \\
\hline Leiognathidae & $\begin{array}{l}\text { Leiognathus brevirostris } \\
\text { Leiognathus splendens } \\
\text { Leiognathus dussumieri } \\
\text { Gazza achlamys } \\
\text { Secutor insidiator }\end{array}$ & $\begin{array}{l}\text { Shortnose ponyfish } \\
\text { Splendid pony } \\
\text { Dussumier's ponyfish } \\
\text { Naked toothpony } \\
\text { Pugnose ponyfish }\end{array}$ \\
\hline Lactariidae & Lactarius lactarius & False trevally \\
\hline Engraulididae & $\begin{array}{l}\text { Thryssa setirostris } \\
\text { Thryssa malabarica }\end{array}$ & $\begin{array}{l}\text { Longjaw thryssa } \\
\text { Malabar thryssa }\end{array}$ \\
\hline Sciaenidae & $\begin{array}{l}\text { Otolithes ruber } \\
\text { Protonibea diacanthus } \\
\text { Johnius carouna }\end{array}$ & $\begin{array}{l}\text { Tigertooth croaker } \\
\text { Spotted croaker } \\
\text { Caroun croaker }\end{array}$ \\
\hline Sphyraenidae & Sphyraena jello & Pickhandle barracuda \\
\hline Mullidae & Upeneus bensasi & Bensasi goatfish \\
\hline Terapontidae & $\begin{array}{l}\text { Terapon jarbua } \\
\text { Terapon puta }\end{array}$ & $\begin{array}{l}\text { Jarbua terapon } \\
\text { Smallscaled terapon }\end{array}$ \\
\hline Sillaginidae & Sillago sihama & Silver sillago \\
\hline Polynemidae & Eleutheronema tetradactylum & Fourfinger threadfin \\
\hline Portunidae & $\begin{array}{l}\text { Portunus pelagicus } \\
\text { Portunus sanguinolentus }\end{array}$ & $\begin{array}{l}\text { Blue swimming crab } \\
\text { Bloodspotted crab }\end{array}$ \\
\hline
\end{tabular}




\section{a. $\log \mathrm{raft} / \mathrm{trammel}$ net}

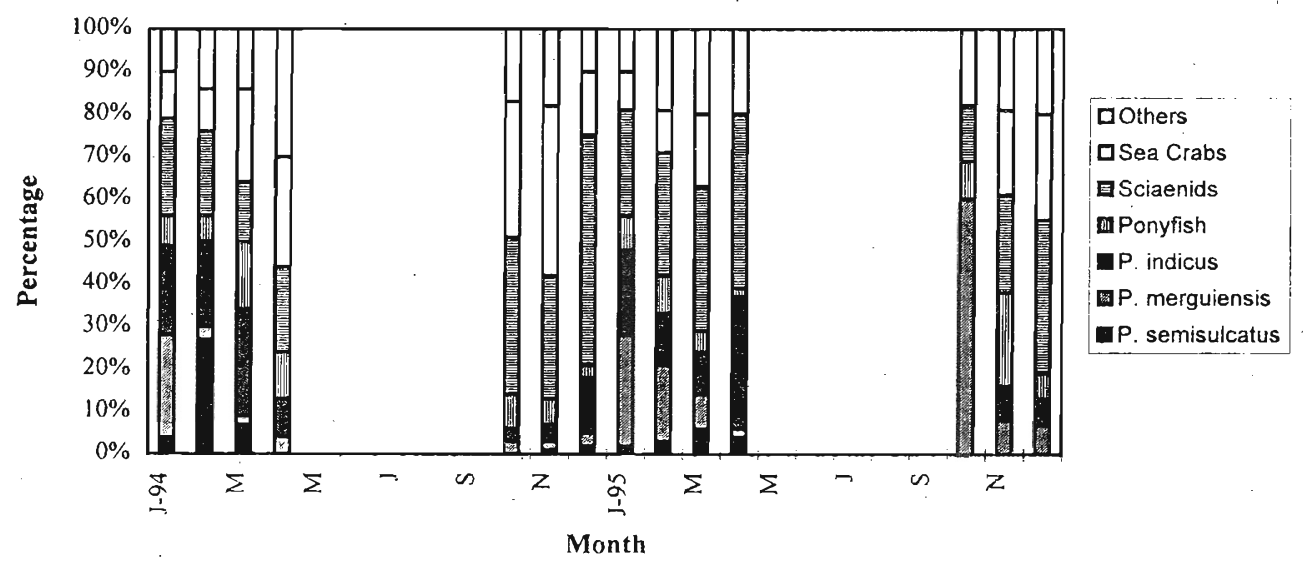

b. FRP/trammel net

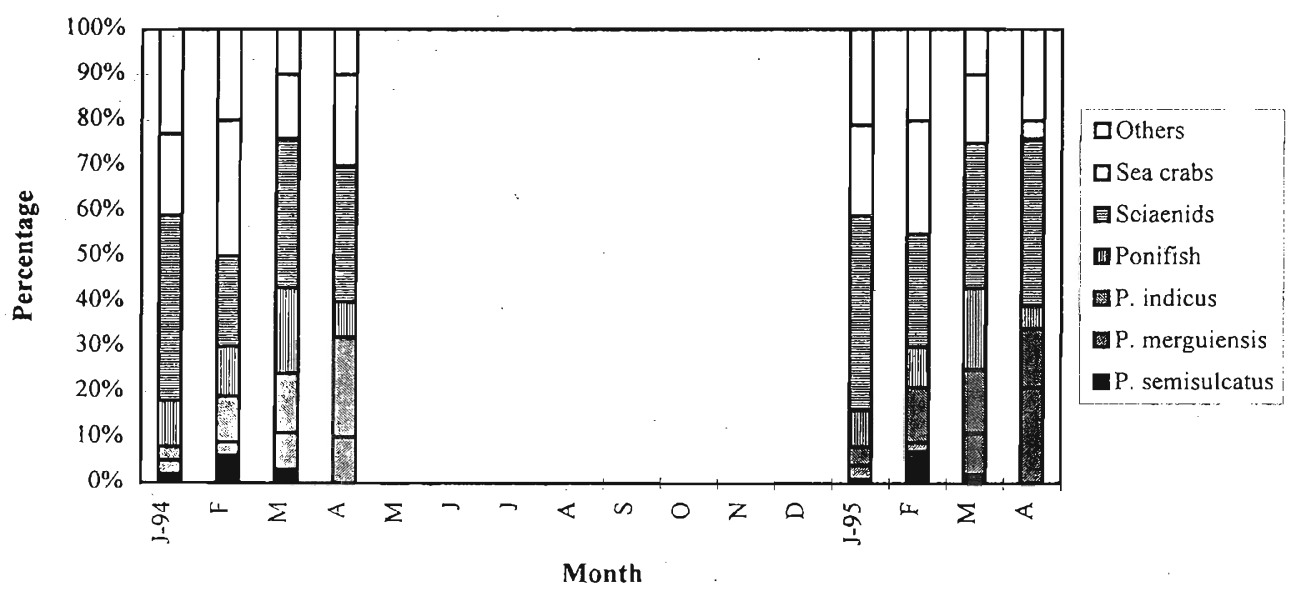

Figure 2: Monthly variation in the species composition of the catch 


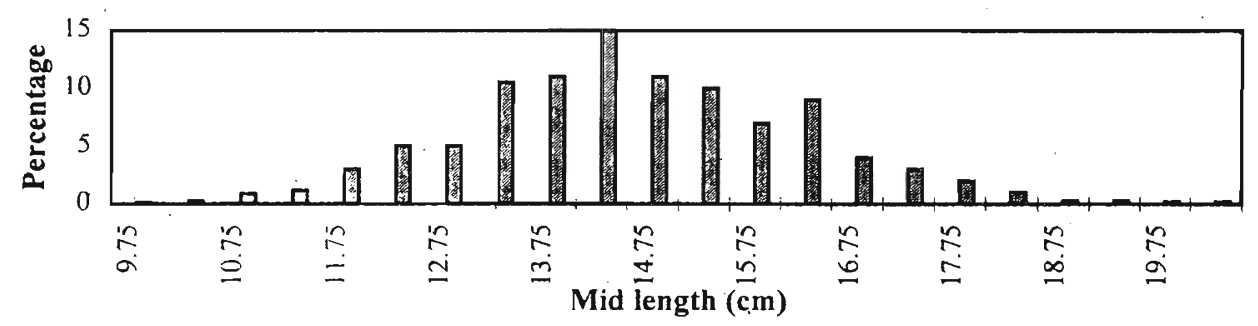

Penaeus indicus

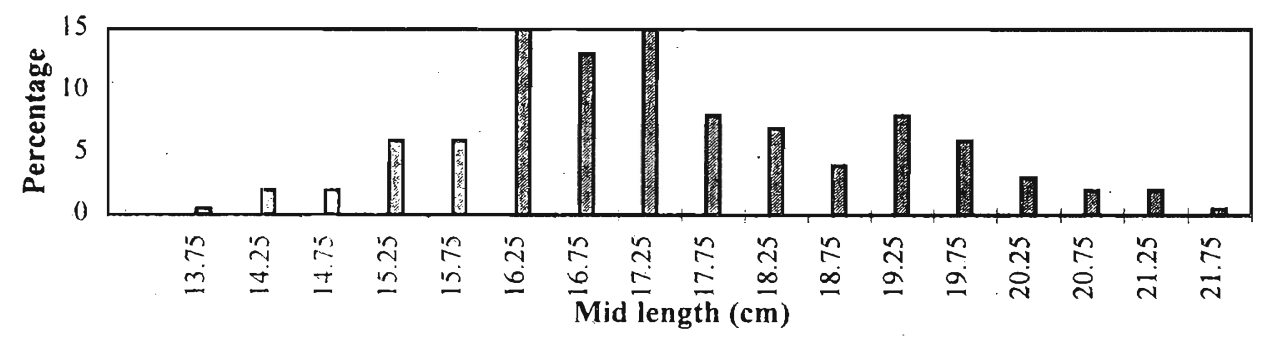

Penaeus merguiensis

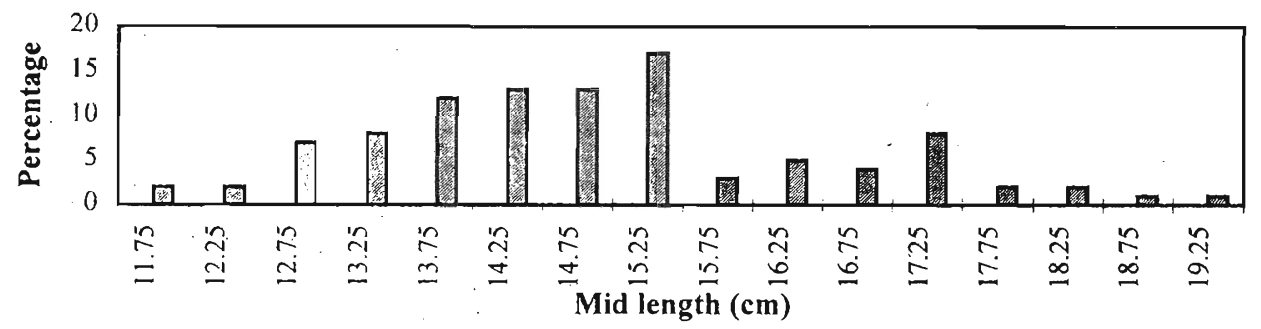

\section{Penaeus semisulcatus}

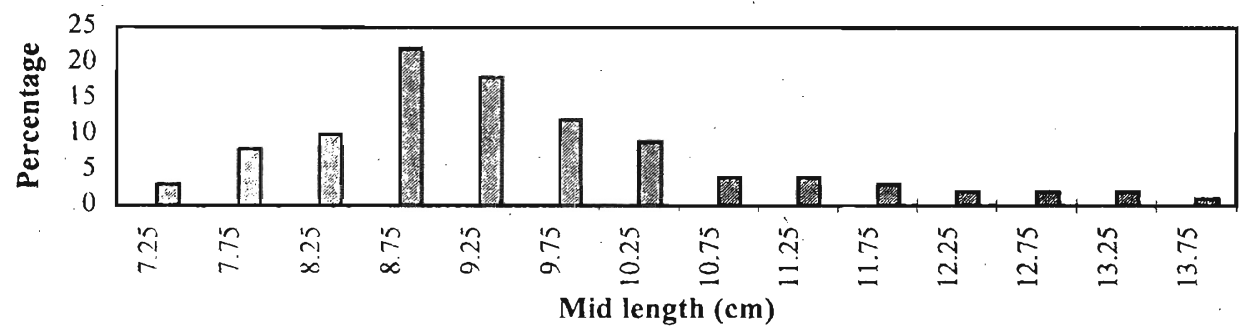

\section{Metapenaeus dobsoni}

Figure 3: Length frequency distributions of the major shrimp species caught in the artisanal prawn fishery. 
of the prawn species caught in this fishery. Length frequency data (Fig. 3) showed that the total lengths of the major prawn species caught in this fishery ( $P$. indicus, $P$. merguiensis and P. semisulcatus) vary from $9.9 \mathrm{~cm}$ to $19.8 \mathrm{~cm}, 13.8 \mathrm{~cm}$ to $21.8 \mathrm{~cm}$ and $11.6 \mathrm{~cm} 19.5 \mathrm{~cm}$ respectively. Small prawns (Metapenaeus spp.) were recorded only among the catches of seasonal fishing operations and small meshed gillnets particularly in January/February period. The total lengths of the Metapenaeus dobsoni caught by seasonal fishing operations and small meshed gillnets varied from $7.1 \mathrm{~cm}$ to $13.6 \mathrm{~cm}$ and $7.3 \mathrm{~cm}$ to $13.7 \mathrm{~cm}$ respectively.

\section{Seasonal fishing operations for small prawns}

Observations were also made on the seasonal fishing operations for small prawns in the study area carried out on an irregular basis. During the present study, these operations took place only in the months of January and February of 1995. The gear used was an encircling gillnet, rectangular in shape (length $=12.3 \mathrm{~m}$, height $=2 \mathrm{~m}$ and mesh size $=7 \mathrm{~mm}$ stretched mesh). The fishing unit consisted of a FRP boat and a traditional log raft with the crew number varying from 4 to 6 . There were around 20 such fishing units in the study area. The estimated average catch rate for the seasonal fishing operations was $62 \mathrm{~kg} /$ operation. The total productivity from these operations was estimated at 17.36 MT.

\section{DISCUSSION}

The variation pattern of the catch rates of the different craft/gear combinations were found to be similar during both years studied. There is a trend for the catch/effort values to increase in October - November and decline to reach a minimum in March. High catch per unit effort values were observed at the beginning of the north east monsoon. Similarly a period with low catch rates coincides with the tail end of the north east monsoon. It is understood that the total catch rate of the prawn fishery is determined by the catch rate of the finfish to a great extent. In addition, the period of high catch/effort for prawns coincides with the estimated spawning season of the penaeid prawns in the west coast of Sri Lanka (August to February). 8,9

In the study area, the total annual production from the artisanal prawn fishery obtained for the 1994 period was $92 \mathrm{MT}$ which was comparatively higher than the production obtained for the 1995 period which was $68 \mathrm{MT}$. In addition the estimated total production from the seasonal fishing operations for small prawns in the seas off Chilaw in 1995 period was around $17 \mathrm{MT}$. However, the comparatively high production obtained in 1994 period could have been probably due to the high average catch rate and the fishing effort of both craft/gear combinations in 1994 which led to a high production in the 1994 period. The production from the artisanal prawn fishery in the study area is quite low when compared to the production from the prawn trawl fishery in Chilaw area during the periods of 1979-1980 and 
1980-1981. Total productions from the prawn trawl fishery in Chilaw area for the periods 1979-1980 and 1980-1981 have been estimated to be 364 MT and 359 MT respectively. ${ }^{\text {s }}$

Contribution of prawns to the total productivity of the artisanal prawn fishery in Chilaw was around $24 \%$ which is comparatively low when compared to that of the prawn trawl fishery in Chilaw area which was around $37 \%$. However, the prawn catches from the artisanal prawn fishery were dominated by the large and more economically important prawn species such as $P$. indicus, $P$. merguiensis and $P$. semisulcatus and the contribution of small prawns (especially the Metapenaeus spp.) to the prawn catches was found to be insignificant. This could have been probably due to the structure of the trammel nets employed in the artisanal prawn fishery which were especially designed to catch large prawn varieties. However, according to Jayakody, the contribution of small prawns to the prawn catches from the trawl fishery in the Chilaw area was significant and it was around $26 \%$.

Prior to the termination of the prawn trawl fishery in the coastal waters off Chilaw in 1992 these two fisheries (artisanal prawn fishery and the prawn trawl fishery) were mainly responsible for prawn catches from Chilaw area. However, after the imposition of the ban on prawn trawl fishery in 1992, the prawn resources in the shallow coastal waters off Chilaw are exclusively exploited by the traditional prawn fishermen which provide livelihood for more than two thousand people scattered throughout the study area. The present investigation shows that the small. prawn varieties which made significant contribution to the prawn catches from the trawl fishery are presently exploited by the seasonal fishing operations which last only for very short period during January/February with the appearance of massive schools of small prawns in the coastal waters off Chilaw.

According to the common understanding of the fishermen these fishing operations are carried out more or less on an irregular basis and during the present study seasonal fishing operations were viable only in 1995 for a short period of a couple of weeks. Therefore, it is possible that this resource is under exploited at the moment. However, prior to making any conclusion on this aspect a detailed study should be conducted to understand the distribution, migration and the stock abundance of the small prawn resources in the study area. Findings of the present investigation would be useful as baseline information for such a detailed study.

\section{Acknowledgement}

The authors thank the National Aquatic Resources Research and Development Agency (NARA) for financial assistance and H. A. R. E. Perera, M. G. K. Gunawardane, T. Upasena, H. D. Wimalasena, D. M. de Mel and S. C. V. U. Senavirathne for their assistance in the field work. 


\section{References}

1. Chitravadivelu K. (1990). Efficiency of main fishing gears used in prawn fishery in the Jaffna Lagoon. Journal of the National Science Council of Sri Lanka. 18 (1) : 37-52

2. Pedni M. (1981). Penaeid shrimp culture in tropical developing countries. FAO fish. Circular 732 : pp. 14

3. Anon (1980). ACDP REPORT (1980). Strategy for development of aquaculture in Sri Lanka. Report of a Planning Mission. Sep. - Oct. 1980. ACDP/MR/81/15

4. Siddeek M. S. M. (1978). Estimating the population density of prawns by use of the catch per effort data from prawn trawlers at Chilaw. Bulletin of Fisheries Research Station of Sri Lanka. $28: 1-26$

5. De Bruin G. H. P. (1970). The distribution of penaeid prawns in Ceylon waters. Bulletin of Fisheries Research Station Ceylon. 22 (1 \&2) : 47-51

6. Jayawickrema S. J. C. (1990). Status of Penaeus indicus stocks from Negombo and Chilaw, Sri Lanka. Journal of the National Science Council of Sri Lanka. $18(2): 159-166$

7. Corea A. S. L. E., Jayasinghe J. M. P. K., Eliaratne S. U. K. \& Johnston R. (1985). Environmental impact of prawn farming on Dutch Canal : The main water source for the prawn culture industry in Sri Lanka. AMBIO. 24: 7 - 8

8. Jayakody D. S. (1984). The fishery and some aspects of biology of commercially important penaeid prawns of the west coast of Sri Lanka. M. Phil. thesis. University of Kelaniya, Sri Lanka.

9. Jayakody D. S. \& Costa H. H. (1988). Population dynamics of Indian Shrimp (Penaeus indicus, Milne Edwards) on the west coast of Sri Lanka. Asian Fisheries Science. $1: 135-146$ 